and varaphrenia. With regard to melancholia and dementia præcox I pointed out how unsatisfactory it was that many clinicians put the cases I had in mind in these groups, and I gave in detall the differential diagnosis.

I quite agree that psycho-analysis would be most harmful in patients suffering from well-marked delusions of persecution or grandeur described by Kraepelin as cases of paraphrenia. On the other hand, in the first stage of chronic hallucinatory psychosis the sole symptom is the presence of hallucinations. These, in my belief, develop owing to mental conflict, and repiession; and then it is that psycho-analysis is likely to be beneficial. As Dr. Stoddart was nnavoid. ably prevented from hearing the paper read. he is no doubt relying on the report of the meeting in THE LANCET of March 20th. This, of course, is very condensed. The paper will appear in full in the next number of the Journal of Mental Science, and if, after studying the clinical cletails of those patients who are given as examples, Dr. Stoldart is still of the opinion that they are cases of paraphrenia I hope he will lenew his attack. After all, what is paraphrenia? It is only Magnan's "délire chronique" served up in a new form. Kraepelin admits as much with regard to paraphrenia systematica.

I am, Sir, your's faithfully

City of London Mental Hospital, near

Dartford, Kent, March 27th, 1920.

R. H. STEEN

\section{TUBERCULOSIS AND PENSIONS.}

To the Editor of THE LANCET.

SIR,- - The note in your last issue on the Diagnosis of Tuberculosis in Recruits and Pensioners by Dr. John Guy is timely. On looking through my records it is surprising to see how many men are getting expext at recounting symptoms which they think will lead to a diagnosis of tuberculosis, and which observation in a sanatorium entirely fails to confirm. Perhaps the most difficult are those who tell a history of hæmoptysis, though many give themselves away by their extravagant statements as to the amount and the circumstances.

To show how many are the cases of deliberate or subconscious malingering I have gone into my records here for the last six months, and find that the figures are sufficiently remarkable to bring before your notice. The cases are sent in by the county tuberculosis officers whenever the history or symptoms appear to indicate that careful clinical investigation may be required to settle the diagnosis. The concentration methods of examining the sputurn in use at the county laboratories (under the control of Dr. S. Barwise, county medical officer of health) settle the diagnosis of some of them quite clearly by the finding of tubercle bacilli, even when in very small numbers. The "negative" cases are given exercise tests with rectal temperature controls, an $X$ ray screen and plate examination is made, and in some cases an attenupt is made to induce focal reactions with tuberculin where there are no contra-indications to such method. The period of observation takes about ten days, and includes careful clinical examinations at different times of the chest.

What have been the results? Out of 103 cases in six months, 25 were "flagrant" cases of tuberculosis with positive sputum ; 5.2 were very early and "closed" cases: and 26 were "non-tuberculous." That is, onequarter of all the admissions of ex-soldiers were negative to all tests, or, as I prefer to put it, not surfering from active or recent tuberculosis. Now, on looking into the statements of these men with regard to their symptoms, one is struck by the fact that they seldom claim less and often more than the "sputum positive" case, shortness of hreath and loss of voice being the most frequent symptoms. If kept in bed uncler close observation many of these cases get tired of the pretence and freely actmit they are now quite well-within a week.

At a time when the tinancial resources of the country are strained to the ntmost it is essential that money should not be frittered away in pensions to the undeserving, and, while it is conceded that the exsoldier should have the benefit of any doubt that may exist, it is very important that all reasonable means to clear up such doubts should be taken. A few pounds spent on a proper diagnosis may save many hundred pounds in pension money, and many a man's selfrespect may be restored by being firmly told that he has no clain to a pension. Hasty diagnosis on the lines of least resistance is more common and more expensive to the countiry in cases of suspected tuberculosis than in any other condition.

I am, Sir, your's faithfully,

W. C. Fowler.

Derbrshire Sanatorium, Chesterfield, Jarch 29th, 1920.

\section{THE DRINKING OF METHYLATED SPIRITS.}

\author{
To the Elitor of THE LANCET.
}

SIR,-Partly on account of the increased cost of whisky, brandy, \&c., and partly because the purchase of these spirits is restricted to a few hours during the day, the drinking of methylated spirits appears to be greatly on the increase. I have had under treatment recently several patients who have taken to methylated spirits when nothing better was obtainable, and there have been references to the practice in the daily press.

A simple method of making this beverage unpopular is to add tartar emetic, $\frac{7}{2}$ gr. to each ounce, and to label the mixture "poison." I have for many years had this addition made to the methylated spirit used for household purposes in an institution with which I am connected, and I believe that the "poison" label has been sufficient to deter the inmates from sampling the stuff. The cost of the addition to all the methylated spirit sold to the public would not be heavy, say $1 d$. a gallon, and the cost of other additions such as shellac or naphtha would be saved, though to colour the mixture blue (which $I$ have never donel might be an advantage. I am, Sir. yours faithfully,

Rickmansworth, Aarch 29 th, 1920. F. S. D. HoGG.

\section{UNIYERSITY COLLEGE, LONDON: WAR MEMORIAL TO FALLEN STUDENTS.}

\author{
To the Editor of THE LANCET.
}

SrR,-We trust you will sive us the hospitality of your columms to call the attention of former students of University College and University College Hospital, London, to the memorial we are endeavouring to raise to college and hospital men who fell in the war. Owing to the many changes that have taken place during and since the war, our address-list is not complete. It will be of great assistance to us if all members of the College who have not already received our appeal will send post-cards with their names and addresses and dates of student years to the honorary secretary. We shall then be very glad to send them full particulars of our war memorial scheme. We hope we may rely on the support of all students. past and present. We are, Sir. your's faithfully,

$$
\begin{aligned}
& \text { GREGORY FOSTER, } \\
& \text { Chairman. } \\
& \text { G. BLACKER, } \\
& \text { Vice-Chaiman. } \\
& \text { LAWRENCE SOLOMON, }
\end{aligned}
$$

Cniversity College. Inndon, Match 25th, 1920. Hon. Secretary.

\section{PAY IN THE INDIAN MEDICAL SERVICE. To the Fitor of THE LANCET.}

SIR,--May I place before your reader's interested in I.M.S. prospects the following facts showing the relatively deteriorated condition of the I.M.S. both in relation to their fellow military officers, and to the other scientific services in India.

Army Instruction India 321 of 1919 fixes a new scale of consolidated pay for I.M.S. officer's, abolishes the station hospital allowances introduced in Indian Army Instruction 1343 of 1918, and continues in force the abolition of all previous allowances enumerated in the latter Indian Army Instruction-viz., additional charge allowances, horse allowances. and plurality of charges.

Indian Army Order No. $86 \&$ fixes a new rate of grade pay for Indian Army regimental officers, but continues 